ISSN:1308-8173

Geliş Tarihi: 09.06.2020
E-ISSN: 1308-8505

Kabul Tarihi: 29.06.2020
YIL: 2020

ÖZGÜN ARAȘTIRMA
Cilt: 35 Sayı: 2 Sayfa: $211-220$

Doi: $10.24988 /$ ije.202035201

\title{
Pandeminin Toplumsal Yansımaları
}

\section{Nükhet HOTAR ${ }^{1}$, Rabia Ece OMAY ${ }^{2}$, Serdar BAYRAK ${ }^{3}$, Ziya KURUÜZÜM ${ }^{4}$, Belgin ÜNAL ${ }^{5}$ Özet}

İlk kez 2019 yılının Aralık ayında Çin'de görülen ve çok kısa sürede pandemiye dönüșen Covid-19, alınan güçlü önlemler sayesinde bulunduğumuz coğrafi konuma göre oldukça geç bir tarihte ülkemizde de ortaya çıkmıştır. Dünya Sağlık Örgütü'nün pandemi ilanı ile beraber Sağlık Bakanlığı'nın geliştirmiş olduğu algoritmalar doğrultusunda Dokuz Eylül Üniversitesi Sağlık Yerleşkesinde de yönetsel ve tıbbi değerlendirmeler gerçekleştirilmiş ve süreç bu prensiplerle sürdürülmeye devam edilmiștir. Çalıșmada Dokuz Eylül Üniversitesi Pandemi Polikliniği'ne bașvuran hastaların tanı kriterlerine bağlı olarak değerlendirilme süreçleri ve buna bağlı sosyo-demografik özellikleri incelenmiş ve uzun vadede toplu izolasyonun sürdürülebilir olup olmadığı, normalleşme sürecinin nasıl sürdürülmesi gerektiği ile ilgili öngörülere de yer verilmiştir. Bu amaçla 18.03.2020-24.04.2020 periyodunda DEÜ Araștırma Uygulama Hastanesinde Covid-19 tanısı ile izlenen hastaların demografik özellikleri dikkate alınmıstır. Covid-19 pandemi süreci bir toplumun en temel ihtiyaçlarından birinin sağlık hizmetleri olduğunu ortaya koymuştur. Bununla birlikte kesin Covid-19 vakalarının diğer Covid-19 vakaları ile temasta bulunmuş olma oranı oldukça yüksektir ve bu nedenle pandeminin yayılımını kontrol altına almak için sosyal izolasyonun sağlanması çok önemlidir. Bununla birlikte kamu ve özel sektörün gerekli önlemleri alarak, kontrollü bir normalleşme sürecine geçmesi büyük önem taşımaktadır.

Anahtar kelimeler:Covid-19, Pandemi, Ekonomik etki, Toplumsal etki Jel Kodu: I18, A13

\section{Social Reflections of the Pandemic}

Abstract

Covid-19 was first seen in China in December 2019. Covid-19 turned into a pandemic in a very short time. Thanks to the strong precautions taken, it appeared in our country at a very late date according to our geographical location. With the announcement of the pandemic of the World Health Organization, administrative and medical evaluations were carried out at the Dokuz Eylül University Health Campus, guided by the algorithms developed by the Ministry of Health. And the process continued with these principles. In the study, the evaluation processes and socio-demographic characteristics of patients admitted to the Dokuz Eylül University Pandemic Outpatient Clinic were examined. In the long term, predictions about whether mass isolation is sustainable and how the normalization process should be continued are also included. For this purpose, the demographic characteristics of the patients who were followed up in the DEU Research and Application Hospital with the diagnosis of Covid-19 during the period of 18.03.2020-24.04.2020 were taken into consideration. The Covid-19 pandemic process we are experiencing reveals that one of the basic needs of a society is health services. In addition, the exact rate of Covid-19 cases contacting other Covid-19 cases is high. Therefore, it is very important to provide social isolation to control the spread of the pandemic. However, taking necessary measures in the public and private sectors and moving to a controlled normalization process is of great importance.

Keywords: Covid-19, Pandemic, Economic impact, Social impact

Jel Codes: I18, A13

ATIF ÖNERİSi (APA): Hotar N, Omay RE, Bayrak S, Kuruüzüm Z, Ünal B. (2020). Pandeminin Toplumsal Yansımaları. İzmir Íktisat Dergisi. 35(2). 211-220. Doi: 10.24988/ije.202035201

1 Prof. Dr., Dokuz Eylül Üniversitesi, Alsancak, İZMİ.nukhethotar@deu.edu.tr

ORCID: 0000-0002-2195-0852

2 Doç. Dr., Dokuz Eylül Üniversitesi, İktisadi ve İdari Bilimler Fakültesi, Buca, İZMİR. rabiaece.omay@deu.edu.tr ORCID: 0000-0002-3819-4563

${ }^{3}$ Doç. Dr., Dokuz Eylül Üniversitesi, Tıp Fakültesi, Narlıdere, IZMİR. serdar.bayrak@deu.edu.tr ORCID: 0000-0003-1458-9023

4 Prof. Dr., Dokuz Eylül Üniversitesi, Tıp Fakültesi, Narlıdere, İZMİR. ziya.kuruuzum@deu.edu.tr ORCID: 0000-0002-1095-8226

5 Prof. Dr., Dokuz Eylül Üniversitesi, Tıp Fakültesi, Narlıdere, İZMIR. belgin.unal@deu.edu.tr

ORCID: 0000-0002-4354-8266 


\section{GíRiş}

Resmi kayıtlara göre ilk olarak 2019 yılının Aralık ayında Çin'in Wuhan eyaletinde saptanan; bulaş merkezi olarak deniz ürünleri ve canlı hayvan pazarından çıktığı düşünülen, daha önce tanımlanmamış bir hastalık kısa süre içinde tüm dünyayı sarıp epidemik bir tabloya neden olmuştur. Çin kaynaklı değerlendirme raporlarında bu pazarda kümes hayvanları, yarasalar ve deniz ürünlerinin satışının yapıldığı belirtilmekteydi. İlk hastalarla birlikte yapılan izolasyon çalışmaları ilginç bir sonucu ortaya çıkarmış; izole edilen mikroorganizmanın daha önce hiç karşılaşılmamış, geçmişte dünyada epidemilere yol açmış Corona virüs ailesinden bir virüs olduğu belirlenmiștir. Çin hükümetinin yapmış olduğu açıklamalarına göre Covid-19 adı verilen bu virüsle ile ilgili bilgi Dünya Sağlık Örgütü'ne (DSÖ) hemen iletilmiş ve gerekli önlemler alınmıştır. Ancak, gelişen süreç içinde virüs tüm dünyaya hızla yayılmış ve kısa sürede DSÖ tarafında küresel çapta pandemi ilan edilmiştir. Ülkemizde alına güçlü önlemler sayesinde ilk vaka bulunduğumuz coğrafi konuma göre oldukça geç bir tarih olan 11 Mart 2020 'de ortaya çıkmıştır.

Dünya Sağlık Örgütü'nün pandemi ilanı ile beraber Sağlık Bakanlığı'nın bilim kurulları bazı algoritmalar oluşturmuştur. $\mathrm{Bu}$ algoritmalara uygun olarak Dokuz Eylül Üniversite (DEÜ) sağlık yerleşkesinde de yönetsel ve tıbbi değerlendirmeler gerçekleştirilmiş ve süreç bu prensiplerle sürdürülmeye devam edilmiştir.

$\mathrm{Bu}$ çalışmamızda Dokuz Eylül Üniversitesi pandemi polikliniğine başvuran hastaların tanı kriterlerine bağlı olarak değerlendirilme süreçleri ve buna bağlı sosyo-demografik özellikleri irdelenmiştir. Bununla birlikte uzun vadede toplu izolasyonun sürdürülebilir olup olmadığı, "normalleşme" sürecinin nasıl sürdürülmesi gerektiği ile ilgili öngörülere de yer verilmiştir.

Çalışmada Dokuz Eylül Üniversitesi Hastanesine başvuran Covid-19 hastalarının tanımlayıcı özellikleri ve buna bağlı olarak sosyal sonuçlar çıkarılması hedeflenmiştir.

\section{METOD}

Bu kesitsel araștırmada araştırma grubunu 18 Mart-24 Nisan 2020 arası dönemde DEÜ Araştırma Uygulama Hastanesine başvurup olası Covid-19 (U07.3) tanı kodu ile izlenen hastalar oluşturmaktadır. Çalışmada hastaların yaş, cinsiyet, meslek gibi demografik özellikleri, yani araştırma grubunu oluşturan hastalara ait bilgiler hastane bilgi sistemi (PROBEL) kayıtlarından elde edilmiştir. U07.3 tanı kodu alan hastaların nazofarengeal sürüntü örnek sonucu Sağlık Bakanlığının Covid-19 hastalarının sürveyansı kapsamında oluşturduğu Halk Sağlığı Yönetim Sisteminden alınmıştır.

\section{COVID-19 PANDEMİ SÜRECINIIN DEMOGRAFİK VERİLERLE DEĞERLENDİRILLMESİ}

Yapılan detaylı veri incelemesi sonucunda sistemde sağlık bakanlığının U07.03 kodu ile bildirim istediği Covid-19 olası tanılı hasta sayısı 18 Mart-24 Nisan tarihleri arasında 3377 olarak tespit edilmiş, bu olası tanıya sahip hastalarda yapılan PCR taramaları sonucunda kesin vaka olarak 442 hasta tanımlanmıștır. $\mathrm{Bu}$ hastaların yapılan değerlendirmelerinde kadın/erkek oranları neredeyse birbiriyle aynı bulunmuştur (Tablo1). Bu kapsamda, cinsiyetin Covid-19 virüsüne yakalanma riski üzerinde doğrudan belirleyici bir etkisi olmadığı söylenebilir.

Tablo 1: Vakaların cinsiyete göre dağılımı.

\begin{tabular}{|l|c|c|}
\hline Cinsiyet & N & $\%$ \\
\hline Kadın & 223 & 50.5 \\
\hline Erkek & 219 & 49.5 \\
\hline Toplam & 442 & 100 \\
\hline
\end{tabular}

Tablo 2: Vakaların yaș durumu.

\begin{tabular}{|c|c|c|c|}
\hline Yaş & $\begin{array}{c}\text { Ortalama } \\
\text { (St. Sapma) }\end{array}$ & En küçük & En büyük \\
\hline & $51.6(22.1)$ & 2 & 96 \\
\hline
\end{tabular}


Tablo 3: Vakaların yaş gruplarına göre dağılımı.

\begin{tabular}{|l|c|c|}
\hline Yaș Grubu & $\mathrm{N}$ & $\%$ \\
\hline 18'den küçük & 12 & 2.7 \\
\hline 18-64 & 301 & 68.1 \\
\hline 65 ve daha büyük & 129 & 29.2 \\
\hline Toplam & 442 & 100 \\
\hline
\end{tabular}

Tablo3' de görülmektedir ki, 18 Mart - 24 Nisan periyodunda, 18 yaş altı nüfusta Covid-19 vakası görülmesi oranı \%2.7'dir. Bilindiği üzere, 11.03.2020 tarihinde ilk Covid-19 vakasının görülmesinin hemen ardından 12.03.2020 tarihi itibarıla Milli Eğitim Bakanlığı ve Yükseköğretim Kurulu tarafından yüz yüze eğitime ara verilmesi ve uzaktan eğitime geçilmesi kararları verilmiştir. 04.04.2020 tarihinde de genç nüfusu korumaya yönelik alınan bir ikinci kararla 20 yaş altındaki nüfusa sokağa çıkma kısıtlaması getirilmişti. Elde edilmiş olan veriler doğrultusunda, gerek yüz yüze eğitimden uzaktan eğitime geçilmesi, gerekse 20 yaş altı nüfusun sokağa çıkma kısıtlaması uygulanmasının, 18 yaş altında vaka oranının düşük kalmasında büyük bir etken olduğu söylenebilir.

Tablo 4: Vakaların onlu yaş gruplarına göre dağllımı.

\begin{tabular}{|l|c|c|}
\hline Yaș Grubu & $\mathrm{N}$ & $\%$ \\
\hline $0-9$ & 2 & 0.5 \\
\hline $10-19$ & 15 & 3.4 \\
\hline $20-29$ & 54 & 12.2 \\
\hline $30-39$ & 86 & 19.5 \\
\hline $40-49$ & 82 & 18.6 \\
\hline $50-59$ & 56 & 12.7 \\
\hline $60-69$ & 30 & 6.8 \\
\hline $70-79$ & 44 & 10.0 \\
\hline $80-89$ & 49 & 11.1 \\
\hline 90 ve üzeri & 24 & 5.4 \\
\hline Toplam & 442 & 100 \\
\hline
\end{tabular}

TÜİK Bölgesel istatistiklerine göre 2019 yılında İzmir ili 0-19 yaș arası nüfusun oranı toplam nüfusa göre \%24.8'dir (TÜİK, 2020). Bu oran dikkate alındığında, DEÜ Hastanesi vakalarında 18 yaș altı nüfusta Covid-19 yayılımının \%2.7 gibi düşük bir oranda kalması uzaktan eğitim ve sokağa çıkma kısıtlamasının doğru bir karar olduğunu göstermektedir.

Tablo3 incelendiğinde 65 yaş ve üstü yaşlı nüfusta vaka oranı toplam vaka sayısına göre \%29.2 olduğu görülmektedir. Bu oran düşük görünmekle birlikte 18 yaş altı nüfusa göre yüksektir. Nitekim TÜİK Bölgesel istatistiklerine göre İzmir ilinde yaşlı nüfusun oranı 2019 verilerine göre \%11.3'dür ve bu oran 0-19 yaş aralığı nüfusun oranından (\%24.8) düşüktür (TÜíK, 2020). Yaşlı nüfus oranının 0-19 yaş aralığı nüfusun oranına göre düşük olmasına karşın yaşlı nüfusun Covid-19 vaka oranının yüksek olmasının birincil sebebi, hastalığın yaşlı nüfusu daha çok etkilemesidir. Belirlenen zaman periyodunda en düșük vefat yaşı 45'dir. Bir diğer faktör olarak da incelenen örnekte vakaların \%20.6'sının huzurevi sakini olması değerlendirilebilir. Yaşlı nüfustaki vaka oranı her ne kadar 0-19 yaş grubuna göre yüksek olsa da 18-64 yaş aralığına oranla düşüktür. Covid-19 yayılımını engellemek amacıyla alınan ilk tedbirlerden biri olan 65 yaş ve üstü vatandaşların sokağa çıkma kısıtlaması uygulanmasının bu oranın düşük olmasında etkili olduğu değerlendirilebilir.

Hastaların yaş ortalaması (22.1 standart sapma ile) 51,6 olarak tespit edilen hasta grubunun yapılan detaylı yaş analizinde (Tablo4) neredeyse her yaş grubunda hasta görülmekle beraber vakaların \%65'e yakınının 20-60 yaş, aralığında olduğu saptanmıştır. $\mathrm{Bu}$ aralıktaki detay analizde ise kümelenmenin daha çok 3050 yaş aralığındaki toplumun üretken ve aktif kesiminde olduğu tespit edilmiștir. Ayrıca bu hasta grubunun yaplan anamnez değerlendirmesinde neredeyse tamamının aktif ve pandemi sırasında çalışıyor olduğu tespit edilmiştir. Aktif çalışan bu hasta grubun \%22.9'luk kısmını sağlık çalışanları oluşturmaktadır. Vakaların \%10.4'ü ise Dokuz Eylül Üniversitesi Tıp Fakültesi (DEÜTF) çalışanıdır (Tablo 5 ve 6). Dolayısıyla sağlık çalışanı olan vakaların \%45'i (yaklaşık yarısı) Dokuz Eylül Üniversitesi Tıp Fakültesi çalışanıdır. 
Tablo 5: Vakaların sağlık çalışanı olma durumu.

\begin{tabular}{|l|c|c|}
\hline \multicolumn{1}{|c|}{ Sağlık Çalışanı } & $\mathrm{N}$ & $\%$ \\
\hline Evet & 101 & 22.9 \\
\hline Hayır & 341 & 77.1 \\
\hline Toplam & 442 & 100 \\
\hline
\end{tabular}

Tablo 6: Vakaların DEÜTF çalışanı olma durumu.

\begin{tabular}{|l|c|c|}
\hline DEÜTF Çalıșanı & $\mathrm{N}$ & $\%$ \\
\hline Evet & 46 & 10.4 \\
\hline Hayır & 396 & 89.6 \\
\hline Toplam & 442 & 100 \\
\hline
\end{tabular}

Tablo7, Tablo8 ve Tablo9 sirasiyla göstermektedir ki, vakaların \%34.4 gibi önemli bir oranı huzurevi ile ilişkilidir. Veriler incelendiğinde vakaların \% 20.6'sının huzurevi sakini, \%12.2'sinin ise huzurevi çalışanı olduğu görülmektedir. Hem yaşlı nüfusu yoğun şekilde barındırması hem de kronik hastalıklar sebebiyle huzur evleri, hastalığa yakalanma ve hastalığın ağır seyretme riskinin yüksek olduğu mekanlardır. Pandeminin yaşandığı ülkelerde Covid-19 sebebiyle yaşanan kayıpların büyük oranda yaşlıların bir arada kaldığı kuruluşlarda görülmesine karşın, T.C. Aile Çalışma ve Sosyal Hizmetler Bakanlığı Engelli ve Yaşlı Hizmetleri Genel Müdürlügü'nün (ailevecalısma.gov.tr) erken dönemde ve ilk Covid-19 vakasının Türkiye'de görülmesinden sonraki süreçte almış olduğu önlemlerle, ülkemizde huzurevleriyle ilişsili vakalar diğer ülkelere göre oldukça düşük oranlarda seyrettiği söylenebilir.

Tablo 7: Vakaların huzurevi ile ilgili olma durumu.

\begin{tabular}{|l|c|c|}
\hline $\begin{array}{c}\text { Huzurevi ile } \\
\text { ilișkili olması }\end{array}$ & $\mathrm{N}$ & $\%$ \\
\hline Evet & 152 & 34.4 \\
\hline Hayır & 290 & 65.6 \\
\hline Toplam & 442 & 100 \\
\hline
\end{tabular}

Tablo 8: Vakaların huzurevi sakini olma durumu.

\begin{tabular}{|l|c|c|}
\hline Huzurevi sakini & $\mathrm{N}$ & $\%$ \\
\hline Evet & 91 & 20.6 \\
\hline Hayır & 351 & 79.4 \\
\hline Toplam & 442 & 100 \\
\hline
\end{tabular}

Tablo 9: Vakaların huzurevi çalışanı olma durumu.

\begin{tabular}{|l|c|c|}
\hline Huzurevi çalışanı & $\mathrm{N}$ & $\%$ \\
\hline Evet & 54 & 12.2 \\
\hline Hayır & 388 & 87.8 \\
\hline Toplam & 442 & 100 \\
\hline
\end{tabular}

Çalışmanın gerçekleştirildiği zaman periyodunda, yurtdışı seyahat öyküsü olan kesin Covid-19 vakalarının oranının \%1.6 olduğu görülmektedir (Tablo10). Ülkemizde, yurtdışı seyahatleri ile ilgili ilk tedbir Wuhanİstanbul uçuşlarının durdurulması ile başlamıştır. İlerleyen süreçte Covid-19 vakalarının görüldüğü ülkelerden gelen yolcuların hava alanlarında termal kameralar ile kontrol edilmesi ve Çin-İstanbul arasındaki tüm uçuşların durdurulması kararları alınmıştır. Türkiye-İran kara hudut kapılarının kapatılması, Umreden gelen kafilelerin tahsis edilen yurtlarda gözlem altında tutulması, Türkiye'nin 68 ülke ile uçuş trafiğini kapatması yönündeki ek tedbirler söz konusu yurtdışı seyahat öyküsü oranının düşük olmasında etkili faktörler olduğu değerlendirilmektedir.

Tablo 10: Vakaların yurtdışı seyahat öyküsü.

\begin{tabular}{|l|c|c|}
\hline Seyahat Öyküsü & $\mathrm{N}$ & $\%$ \\
\hline Evet & 7 & 1.6 \\
\hline Hayır & 435 & 98.4 \\
\hline Toplam & 442 & 100 \\
\hline
\end{tabular}

Tablo 11: Bilinen Covid-19 vakası ile temas durumu.

\begin{tabular}{|l|c|c|}
\hline \multicolumn{1}{|c|}{ Vaka ile teması } & $\mathrm{N}$ & $\%$ \\
\hline Evet & 298 & 67.4 \\
\hline Hayır & 144 & 32.6 \\
\hline Toplam & 442 & 100 \\
\hline
\end{tabular}

Kesin Covid-19 vakalarının \%67 gibi büyük bir oranda bilinen Covid-19 vakası ile teması bulunmaktadır. Bu oran pandeminin yayılımını kontrol altına almak için alınan önlemlerin ve sosyal, bir diğer ifade ile fiziksel izolasyonun önemini ortaya koyan bir değerdir. Süreç boyunca vatandaşlar geleneksel ve sosyal medya gibi yeni araçlar ile bilgilendirilmeye devam edilmeli, sağlık otoriteleri tarafından yapılan açıklamalara itibar edilmesi ve uyulması gerektiği hatırlatılmalıdır. Bir diğer 
önemli husus da risk grubunda yer alan bireylerin veya hastalığı taşıyan, ancak hafif seyir etmesi nedeni ile evden gözlemlenen bireylerin süreç içerisinde resmi makamlarca oluşturulmuş yardım gruplarından destek almalarının da teşvik edilmesidir. Her ne kadar ülkemizde birbiri ile yardımlaşma kültürü yaygın olsa da, özellikle şahsen tanışılmayan bireylerden veya kurumlardan yardım talebinde bulunmaktan kaçınılabileceği göz önünde bulundurulmalı, yardım talep etmenin özellikle böyle bir dönemde bireyin sadece kendisi için değil, çevresi için de hayat kurtarıcı olabileceği vurgulanmalıdır.

Dünya Sağlık Örgütü'nün (DSÖ) 8 Mayıs 2020 tarihinde vermiş olduğu DSÖ bölgelerine göre Avrupa Bölgesi'nde doğrulanmış Covid-19 vaka sayıları incelendiğinde, diğer Avrupa ülkelerinden farklı olarak Sürü Bağıșıklığı sistemini benimseyen İsveç için 24623 ve Hollanda için 41774 vaka olduğu görülmektedir (DSÖ, 2020) Sürü bağışıklığı sistemini benimseyip daha sonra bu stratejiden vazgeçen İngiltere'de ise doğrulanmış vaka sayısı 206.719'dur. Türkiye'de ise 133.721 doğrulanmış vaka bulunmaktadır. Nüfus büyüklüğü açısından bu ülkeler değerlendirildiğinde, İsveç'in nüfusu yaklaşık 11 milyon, Hollanda'nın nüfusu yaklaşık 18 milyon, İngiltere'nin nüfusu yaklaşık 56 milyon ve Türkiye'nin 82 milyondur. Bu ülkelerdeki doğrulanmış vaka sayılarını toplam nüfusu dikkate alarak değerlendirdiğimizde, doğrulanmış vaka oranı en düşük olan ülkenin Türkiye olduğu görülmektedir. Diğerlerine göre Türkiye'nin bu kadar yüksek oranda nüfusa sahip olmasına karşın doğrulanmış vaka oranlarının daha az olmasındaki en büyük faktör, Covid-19 vakası ile temas ederek bulaşmayı en aza indirmek ve hastalığı kontrol altında tutmak için devlet idaresinin gerekli tedbirleri hızlı ve kararlı bir şekilde alması, aynı zamanda vatandaşlar tarafından da bu tedbirlere büyük oranda uyulmasıdır.

21 Nisan 2020 tarihli TÜBA Covid-19 Pandemi Değerlendirme Raporu'na göre aktif vaka sayısındaki büyüme oranını gösteren büyüme hızının hala pozitif bölgede olmasına karşın büyüme hızında sürekli bir düşüş gözlenmektedir (Şeker vd., 2020). Bu düşüșün sürekliliğini sağlayabilmek ve olası bir ikinci dalga riskini ortadan kaldırmak ve başarılı bir "Normalleşme Süreci" için çalışanların sosyal mesafe kurallarına, kişisel hijyene dikkat etmesi gerekmektedir. Bununla birlikte çocukların da yetişkinler kadar hastalığ bulaştırma riski taşıyor olması nedeni ile okullarda önlemlerin ciddiyetle uygulanması da büyük bir önem taşımaktadır.

Tablo 12: Vakaların meslek durumu.

\begin{tabular}{|l|c|c|}
\hline \multicolumn{1}{|c|}{ Meslek } & $\mathrm{N}$ & $\%$ \\
\hline Emekli & 119 & 26.9 \\
\hline Ev hanımı & 55 & 12.4 \\
\hline Doktor & 26 & 5.9 \\
\hline Diğer sağlık çalıșanı & 15 & 3.4 \\
\hline Hemşire & 15 & 3.4 \\
\hline Hasta bakıcı & 16 & 3.6 \\
\hline Öğrenci & 22 & 5.0 \\
\hline Öğretmen & 6 & 1.4 \\
\hline Memur & 26 & 5.9 \\
\hline İşçi & 27 & 6.1 \\
\hline Şoför & 10 & 2.3 \\
\hline Temizlik personeli & 12 & 2.7 \\
\hline Așçı & 7 & 1.6 \\
\hline Güvenli görevlisi & 5 & 1.1 \\
\hline Çalıșmiyor & 25 & 5.7 \\
\hline Diğer & 56 & 12.6 \\
\hline Toplam & 442 & 100 \\
\hline
\end{tabular}

Dokuz Eylül Üniversitesi Araştırma Uygulama Hastanesi kesin Covid-19 vakalarının \%26,9 gibi büyük bir oranını emekliler oluşturmaktadır. Bu yüksek oran aynı zamanda vakaların önemli bir oranının huzurevi sakini olması ile de açıklanabilir. Diğer taraftan aktif çalışma yaşamında olmayan ev hanımlarının oranı da diğer meslek gruplarına göre yüksektir $(\% 12,4)$. Kesin Covid-19 tanisı konulan çalışmayanların oranı ise \%5,7'dir. Emekliler, ev hanımları ve çalışmayanlar diğer bir ifadeyle aktif çalışma hayatında yer almayan Covid-19 vakalarının oranı \%45'dir. Öğrenci ve öğretmen vakaları oranı sırasıyla $\% 5$ ve $\% 1,4$ 'dür. YÖK ve Milli Eğitim Bakanlığı'nın aldığı eğitime ara verme ve uzaktan eğitime 
geçme kararları da göz önünde bulundurulduğunda söz konusu değerlerin düşük çıkması olağandır. Doktorlar, hemşireler, hasta bakıcılar ve diğer sağlık çalışanlarının oranı ise \%16,3'dür. Enfeksiyonu kapma riski en yüksek olan meslek grubunun sağlık çalışanları olduğu gerçeği dikkate alındığında, bu oranın diğer meslekler ya da meslek gruplarına göre (aktif çalışma hayatında olmayanlar hariç tutularak) yüksek çıkması da yine beklenen bir durumdur.

Çalışmada buraya kadar hastaların cinsiyeti, yaşı, sağlık çalışanı olması, DEÜTF olması, huzurevi çalışanı/sakini olması, yurt dışı seyahat öyküsü, bilinen Covid-19 vakası ile temas durumu ve meslek durumları incelendikten sonra bu bilgiler ve sonuçlar ışığında, bir sonraki bölümde özellikle sağlık sektörü başta olmak üzere, diğer sektörlerde pandeminin etkileri, sosyal izolasyon ve normalleșme süreci incelenmiștir.

\section{PANDEMININ TOPLUMSAL VE EKONOMIKK ETKILERI}

Pandemi sürecine küresel açıdan bakıldığında, Avacant LLC tarafından açılklanan "Covid-19'un Sektörlere Göre Etki Raporu"na göre sağlık sektöründe Covid-19'un etkisi çok yönlü olacaktır $\mathrm{Bu}$ sadece sağlık hizmetlerinin sunumunu değil, sağlık yönetimi ve sağlıkta yöneticilik anlayışını da derinden etkileyecek sonuçlara neden olacaktır. Pandemi sürecinde sağlık hizmetlerinin yanı sıra sağlık ürünlerine olan ihtiyaç da oldukça artmıştır. Buna karşın, Çin'deki hammadde sıkıntısı ve fabrika kapanışlarının ilaç sıkıntısına sebep olacağı beklenilmektedir. Diğer taraftan salgın şüphesiz ki hastane ihtiyaçlarını da artırmıștır. Personel, operasyonlar, tedarik zinciri ve gelir faktörleri açısından etki derecelendirmelerine bakıldığında, Covid-19'un küresel boyutta sağlık sektörüne etkisi olumlu ve olumsuz ekonomik etkilerin bir karışımı olarak önemli düzeyde ortaya çıkmaktadır. Araştırmaya göre pandemi sürecinden çok yüksek seviyede etkilenen sektörler imalat, seyahat ve ulaşım sektörleri iken yüksek seviyede etkilenenler ise enerji ve kaynaklar, sağlık ve eğitimdir. Bu etkilenme elbette ekonomik sonuçlar bakımından ele alınmaktadır (Şekil 1). Ancak bir diğer "etkilenme" biçimi de sürecin yönetilmesi ve yeni "normal"e uyum sağlanmasında da kendini göstermektedir. Yönetsel açıdan bakıldığında yeni duruma uyum sağlama, bu yönde yeterli kabiliyetin olup olmaması da sektörleri, büyük ve küçük işletmeleri etkilemektedir (Avasant, 2020). Yukarıda da bahsedilen sektörler açısından, Covid-19 pandemi sürecinin olası etkileri dikkate alınarak "İşverenin kendi sevk ve idaresinden kaynaklanmayan, önceden kestirilemeyen, bunun sonucu olarak bertaraf edilmesine imkân bulunmayan, geçici olarak çalışma süresinin azaltılması veya faaliyetin tamamen veya kısmen durdurulması ile sonuçlanan dışsal etkilerden kaynaklanan dönemsel durumları ya da deprem, yangın, su baskını, heyelan, salgın hastalık, seferberlik gibi durumlar" olarak tanımlanan, "zorlayıcı sebep" kapsamında kısa çalışma uygulaması başlatılmıştır (İŞKUR, 2020). Bu kapsamda çalışanlara kısa çalışma ödeneği ödenmesi sağlanmıştır.

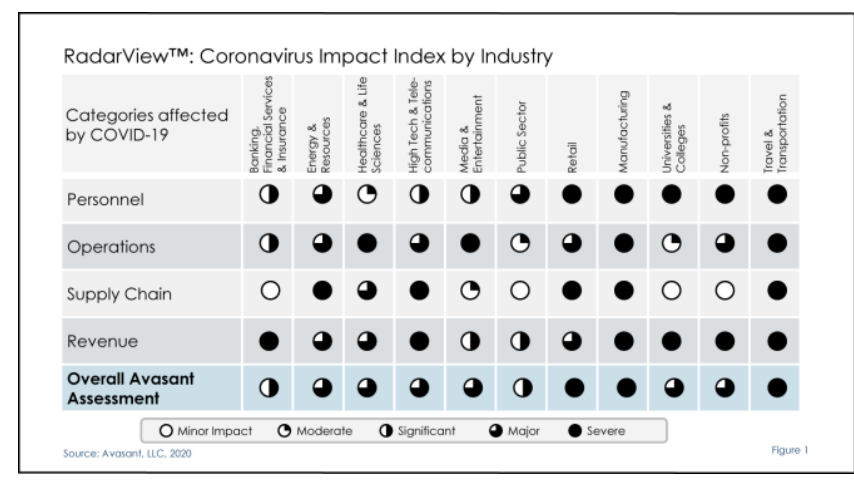

Şekil 1: Covid-19 etki endeksi (Kaynak: Avasant 2020).

TÜBA'nın Covid-19 Pandemi Değerlendirme Raporuna göre Çin'in büyük ölçekli üretimi yerine daha küçük ölçekli, daha güvenilir ve daha kaliteli üretim modelinin bu dönemde daha çok ortaya çıkacağı öngörülmektedir. Pandeminin ortaya çıkardığı olası ekonomik faydalardan yeteri kadar yararlanılabilmesi için Türkiye'nin yeni pazarlara açılmasının ve bu pazarlardaki ekonomik faaliyetlerin artırılması önem arz etmektedir. Pandeminin Türkiye ekonomisi üzerindeki etkileri 
açısından bakıldığında, Avrupa ve Afrika pazarlarına Amerika pazarlarını da eklemenin bir kazanım olacağıdır (Şeker v.d., 2020). Nitekim uluslararası danışmanlık şirketi Kearney, “Türkiye'yi Geleceğin Küresel Değer Zincirlerinde Konumlandırmak" adlı raporunda, pandemi sonrası değişimlerden en çok fayda sağlayacak ülkelerden birinin Türkiye olduğunu belirtmektedir. Türkiye'nin bu süreçte öne çıkmasını sağlayacak faktörlerden birisi, rapora göre salgının etkisiyle tedarik zincirlerinin kısalması ve Avrupa ülkelerinin Türkiye gibi yakın yerlerde üretim yaptırmayı tercih edecek olmasıdır. Raporda iyimser senaryoda pandemi sonrasi dönemde Türkiye'nin toplam ihracatının yıllık 16 milyar dolar artış göstereceği tahmin edilmektedir. Muhafazakar senaryoda ise bu artışın 10 milyar dolar olması beklenmektedir (www.deik.org.tr, 2020).

Covid-19 pandemisi bir toplumun en temel ihtiyaçlarından birinin sağlı hizmetleri olduğunu bir kez daha ortaya koymuştur. $\mathrm{Bu}$ süreçte dünya ülkeleri büyük oranda zarar görmesine karşın Türkiye'nin bu süreci başarılı bir şekilde yürütmesinde, sağlık sistemlerine yaptığı ciddi yatırımlar, donanımlı hastaneler, yatak sayılarının oldukça fazla olması, zamanında teşhis, vatandaşların sağlık sistemine ücretsiz erişiminin olması, karantina süreçlerinin doğru bir şekilde yürütülmesi, yetişmiş sağlık personeli, Türkiye'nin kriz yönetim becerisinin yüksek olması ve Cumhurbaşkanı tarafından açıklanan, Hazine ve Maliye Bakanlığı tarafından yürütülen ekonomik kalkınma paketinin hayata geçirilmesi özellikle İtalya, İspanya, Fransa gibi Avrupa ülkelerinin çok ötesinde Almanya ve Güney Kore gibi ülkelere neredeyse denk, etkin bir süreç yönetiminin önemli faktörleri olarak karşımıza çıkmaktadır. Aynı sebeplerle Türkiye pandemi sonrası sürece hazır ülkeler arasında yer almaktadır. Pandemi sonrasında Türkiye Cumhuriyeti Dıșișleri Bakanlığ Stratejik Araştırmalar Merkezinin Covid-19 Sonrası Küresel Sistem konulu derleme yayınında Türkiye'nin sağlık konusunda sahip olduğu gelişmeleri daha üst seviyelere taşıması ve bunların kalıcılığını sağlaması için, ilaç endüstrisinde bilimsel, teknolojik ve sinai yatırımların kayda değer ölçülerde artırılmasının gerekliliği vurgulanmıştır (Ulutaş, 2020).

Covid-19 pandemi sürecinde yaşanan sosyal izolasyon, özellikle eğitim ve iş dünyasında uzaktan erişime geçme sürecini normal süreçte olmayacak kadar hızlandırmış ve neredeyse insanların tamamının uzaktan erişime alışması ve adapte olmasını sağlamıştır. Kamuda ve özel sektörde online toplantılar, konferanslar, söyleşiler vb. mekandan bağımsız yeni bir yaşam ve çalışma sistemi hızlı bir şekilde hayatımıza girmiştir. $\mathrm{Bu}$ durum yeni teknolojilerin geliştirilmesi için büyük fırsatlar doğurmakla birlikte, özellikle aktif olarak çalışma hayatı içerisinde yer alan bireylerin dijital dönüşüm için daha yetkin ve donanımlı olabilmek amaciyla bugünden gerekli hazırlıkları yapmaları gerektiğini de gözler önüne sermiştir. Pandemi ile birlikte toplumun büyük bir kesimi uzaktan eğitim, uzaktan çalışma, sosyal/fiziki izolasyon, uzaktan/sanal alışveriş vb. kendileri için "yeni" olan kavramlar ve uygulamalar ile tanışmış, toplumun büyük kesimleri hızlı bir biçimde sürece adapte olmaya çalışmıştır. Bu kapsamda, özellikle teknolojiye daha yavaş adapte olan yetişkinler için "uzaktan çalışma" kavramı ile birlikte "sürekli eğitim" kavramı da bir kez daha bir gerçeklik olarak ortaya çıkmıştır. Özellikle "Sürekli Eğitim Merkezleri" gibi merkezlerin konuyu detaylıca ele alıp, çalışma hayatında özellikle tekonolojik yetkinlikleri düşük olan bireylerin bu yetkinliklerini geliştirmelerine odaklanacak eğitimler sunması fayda sağlayacaktır. Bireylerin yanı sıra şirketler de çalışanlarının "uzaktan çalışma" konusunda yetkinliklerini artırmalıdır. Bu kapsamda sadece bireysel değil, kurumsal eğitimlere ve "uzaktan çalışma kültürünün" oluşturulmasına ihtiyaç vardır.

Pandemi süreci ile birlikte oraya çıkan bir diğer algı durumu ise bilginin günümüzde aslında oldukça kolay erişilebilir olması gerçeğidir. Uzaktan eğitime geçmesi ile birlikte birçok ders 
içeriğinin yanı sıra araştırmalar, bilimsel çalışmalar, makaleler, kitaplar çevrimiçi ortamda ücretsiz olarak sunulmaya başlanmıştır. $\mathrm{Bu}$ durum, bireylerin bilgi kaynaklarına daha kolay erişebilmesini olanaklı kılmıştır.

Bununla birlikte, birçok ülkede olduğu gibi pandemi ülkemizde de bireylerin sosyal medyaya daha fazla yönelmesine ve bu ortamlarda sosyalleşmeye çalışmasına neden olmuştur. Bu da, özellikle pandemi ile ilgili bazı doğru olmayan bilgilerin yaygınlaşması açısından bir tehlike arz etmektedir. Toplumda medya, özellikle sosyal medya okur yazarlığının artırılması, özellikle resmi otoritelerden gelmeyen bilgilerin her zaman kuşku ile karşılanması gerektiğinin vurgulanması ve bu yönde aydınlatıcı çalışmalar yapılması gerekli görülmektedir. Nitekim Cumhurbaşkanlığı İletişim Başkanlığ da bireyler ve kurumlar için önemli bir iletişim mecrası konumuna gelen sosyal medyanın doğru kullanımına yönelik bir rehber niteliğinde "Sosyal Medya Kullanım Kılavuzu" da hazırlamıştır (iletişim.gov.tr, 2020).

Dijital teknoloji ve sosyal medya, dünyanın birçok ülkesinde olduğu gibi ülkemizde de pandeminin "nasıl üstesinden gelindiğinin" aktarıldığı bir alan olarak da karşımıza çıkmaktadır. Avrupa'da belki de ilk defa evlerin balkonu birer sosyalleşme alanı olarak kullanılmış, dijital teknolojiler ile aslında oldukça geleneksel bir uğraş olan ekmek yapma teknikleri bile binlerce izleyici bulmuştur. Diğer taraftan ülkemizde pandemi, toplumsal sevinçlerin bir arada yaşanmasına engel olmamış, balkonlar, evlerin içerisi birer sosyalleşme alanına dönüşmüștür (iletişim.gov.tr, 2020)..

\section{SONUÇLAR}

Tarihte olduğu gibi günümüzde de pandemi, toplumların adeta tüm unsurları ile içerisinde yer aldığı topyekun bir savaş halidir. Özellikle Covid-19 gibi bireyler arasından oldukça hızlı yayılan bir virüs ile mücadelede hiçbir zaman sadece devlet otoritesinin karar alması yeterli değildir. Toplu izolasyon, kimileri tarafından virüs ile baș edebilmede "ideal savaș" yöntemi olarak görülse de, uzun vadede sürdürülebilir bir yaklaşım olarak da görülmemektedir. Gerek virüs ile olan mücadelede sağlık kuruluşlarının gerekse tüm toplumun ihtiyaçlarının giderilmesi toplu izolasyon ortaminda mümkün olmayacaktır. $\mathrm{Bu}$ sadece üretim araçlarına veya tüketim ürünlerine yönelik bir ihtiyaç ile sınırlı olmayıp, aynı zamanda sosyal bir yaşamda aktif olarak rol alan bireylerin beden ve ruh sağlığı için de önem taşımaktadır. Bireylerin yaşadığı korku ve kaygılar, sosyal hayattan kopuş, özellikle de nüfusun yoğun olarak toplandığı büyükşehirlerde küçük apartman dairelerinde adeta hapis kalmış olmanın ruh ve beden sağlığına etkileri gelecekte gerçekleştirilecek bilimsel araştırmaların çalışma alanını oluşturması muhtemeldir. Bu açıdan da bakıldığında, kamu ve özel sektörün gerekli maksimum önlemleri alarak faaliyetlerine devam etmesi, vakaların yatay seyrini sürdürecek şekilde kontrollü bir "normalleşme" sürecine geçilmesi büyük önem arz etmektedir. $\mathrm{Bu}$, sadece ekonomik açıdan değil, birey ve toplum sağlığı açısından da önem taşımaktadır. Bununla birlikte bu normalleşme sürecinde ülkemizde farklı sektörler ve/veya meslek grupları tarafından alınması gereken önlemler, uyulması gereken kurallar da Sağlık Bakanlığı Koronavirüs Bilim Kurulunun önerileri doğrultusunda hazırlanan rehberler aracılı̆̆ı ile paylaşılmaktadır.

Bununla birlikte özellikle uzaktan eğitim ve uzaktan çalışma kavramlarının gelecekte de bir süre varlığını sürdüreceği görülmektedir. Bazı şirketler çalışanlarının bir kısmının pandemi sonrasında da uzaktan çalışmaya devam edeceğini açıklamakta; eğitim kurumları ise pandemi ile elde edilen "uzaktan eğitim" kazanımlarının gelecekte farklı eğitim olanaklarının sunulması açısından faydalı görmektedir. Ancak gerek öğrencilerin, gerek eğitmenlerin; gerekse şirketlerin ve çalışanlar için uzaktan eğitim/çalışma rehberlerinin oluşturulmasının, bu yönde toplumda bir kültür oluşturulmasının da gerekli olduğu görülmektedir. 
Diğer taraftan, çalışmaya konu olan Dokuz Eylül Üniversitesi Araştırma Uygulama Hastanesi Covid-19 vakalarının meslek grubu verileri incelendiğinde, pozitif vakalarda büyük oranda aktif olarak iş yaşamı içerisinde olmayan emekli ve ev kadını kategorisinin öne çıktığı görülmektedir. Bu bağlamda, özellikle virüs tarafından kolaylıkla etkilenen yaşlı nüfus ile birlikte yakınlarının bilinçlendirilmesi ve her ne kadar ülkemizde özellikle yaşlı bakım evlerinde yaşanan vaka sayıları diğer bazı ülkeler ile karşılaştırıldığında daha az olsa da bu kapsamdaki ortamların kontrol altında tutulması, yakinen izlenmesi elzemdir.

Bir diğer yoğunluk ise sağlık çalışanlarında görülmektedir. Daha önceden de belirtildiği üzere, enfeksiyonu kapma riski en yüksek olan meslek grubunun sağlık çalışanları olması, pozitif vaka oranlarının diğer meslek gruplarına göre daha yüksek çıkmasını da beraberinde getirmektedir. 7/24 hizmetin sunan, büyük fedakarlıkları ile görevlerini yerine getiren sağlık çalışanları da yine desteklenmeye devam edilmeli; ekipmanın ve ortamların sunmakta oldukları hizmeti minimum risk ile yerine getirmesini sağlayacak şekilde kurgulanmalıdır.

Eğitimde alanında alınan önlemler ile 20 yaş altı gençlere sokağa çıkma kısıtlamasının getirilmesinin genç nüfusta vaka sayısının büyük oranda az olmasında etken olduğu söylenebilir. Daha az dikkatli ya da daha "cesur" olan gençlerin ve çocukların alınan önlemler ile korunmuş olması, isabetli bir karardır.
Bu kapsamda, özellikle normalleșme sürecinde bireyler arasında fiziksel mesafenin korunması, maske takılması, kișisel ve ortam temizliğine dikkat edilmesi, belirli alanlarda belirli sayıdan daha fazla kişinin bulunmaması gibi koruyucu önlemlerin titizlikle uygulanması ve uygulandığının denetlenmesine ihtiyaç olduğu açıktır. Toplumun virüs ve alınması gereken bireysel önlemler açısından bilgilendirilmesi, kişisel ve ortam hijyeni açısından bilinçlendirilmesi gelecek süreçte üzerinde önemle durulması gereken konulardan olacaktır. Virüsün kendiliğinden ortadan kaybolmayacağı ve aşı bulunma sürecinin de belirli bir zaman alacağı gerçeğinden hareket ile toplumsal farkındalığın artırılması elzem gözükmektedir. Bu noktada devlet otoritesinin yanı sıra bilim insanlarının, sağlık çalışanlarının, toplumdaki fikir önderlerinin, medyanın güçlü bir biçimde yapılması gerekenleri tekraren hatırlatması önem taşımaktadır.

Covid-19 virüsü ve yaşanmakta olan zaman dilimi, gelecekte sadece sağlık ve fen bilimleri ile tıp tarihinin bir inceleme alanı olmayacaktır. Tüm dünya ile birlikte ülkemizde de yaşamakta olduğumuz süreç farklı bilim alanlarının ayrı ayrı ve ortak çalışmalarına konu olacaktır. Sürecin insan yaşamına olan sosyal, kültürel, ekonomik etkileri; ülkelerin ulusal ve uluslararası politikalarına etkileri gibi makro ve mikro ölçekte sonuçları farklı boyutları ile ele alınacaktır. $\mathrm{Bu}$ açıdan bakıldığında, gelecekte 2020 yılının "artık hiçbir şey eskisi gibi olmayacak çağı”nın başlangıcı olarak anılması muhtemeldir.

\section{KAYNAKÇA}

Aile Çalışma ve Sosyal Hizmetler Bakanlığı Engelli ve Yaşlı Hizmetleri Genel Müdürlüğü Koronavirüs Bilgilendirme Rehberi I-II https://ailevecalisma.gov.tr/eyhgm/yayinkaynak/, 2020.

Aile Çalışma ve Sosyal Hizmetler Bakanlığı Engelli ve Yaşlı Hizmetleri Genel Müdürlüğü Yaşllar için Bilgilendirme Rehberi III https://ailevecalisma.gov.tr/eyhgm/yayinkaynak/, 2020.

Aile Çalışma ve Sosyal Hizmetler Bakanlığı Engelli ve Yaşlı Hizmetleri Genel Müdürlügü 65 Yaş Üzeri Yaşlılar ve Kronik Hastalığı Bulunan Yaşlılara Yönelik Koronavirüs Bilgilendirme RehberiIV https://ailevecalisma.gov.tr/eyhgm/yayinkaynak/, 2020. 
Avacant "Covid-19'un Sektörlere Göre Etki Raporu"

https://info.avasant.com/coronavirus-impactindex-by-industry, 2020.

Cumhurbaşkanlığı İletişim Başkanlığı Sosyal Medya Kullanım Kılavuzu https://www.iletisim.gov.tr/uploads/docs/So syalMedyaKullanimKilavuzu.pdf, 2020.

Dünya Sağlık Örgütü Covid-19 Durum Raporu109

https://www.seyahatsagligi.gov.tr/site/Haber Detayi/2365, 2020.

IŞKUUR, Kıalışma Ödeneği https://www.iskur.gov.tr/isveren/kisacalisma-odenegi/genel-bilgiler/, 2020.

Şeker, M., Özer, A. Tosun, Z., Korkut, C., Doğrul, M. (2020) "TÜBA Covid-19 Pandemi Değerlendirme Raporu", Türkiye Bilimler
Akademisi Yayınları, TÜBA Raporları No: 34, Ankara

http://www.tuba.gov.tr/tr/yayinlar/suresizyayinlar/raporlar/covid-19-pandemidegerlendirme-raporu , 2020.

TÜIKK Bölgesel İstatistikleri https://biruni.tuik.gov.tr/bolgeselistatistik/ , 2020.

https://www.deik.org.tr/basin-aciklamalarihazine-ve-maliye-bakani-berat-albayrak-deiktalks-programinda-is-dunyasinin-sorulariniyanitladi, 2020 .

Ulutaş, U. (2020) "Covid-19 Sonrası Küresel Sistem: Eski Sorunlar Yeni Trendler", Dışişleri Bakanlığı Stratejik Araştırmalar merkezi SAM Yayınları, Ankara http://sam.gov.tr/tr/wpcontent/uploads/2020/04/sam-covidkitap.pdf, 2020. 